Mirch 2, 1938

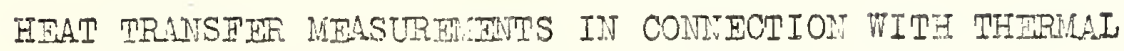

\section{INSUIATION OF IOH-COST HOUSING}

The objectives, procodure, and scope of the Burcau rescarch program on buildinf matcrials with rospect to thoir uso in lov-cost housing, arc outlined in Letter Circliar 502. Fach separate projoct is describod in detail in an additional lettor circular such as this. Waile the resoarch as a wholo doals mainly with studics of structural olononts, it includes consideration of special problors such as durability, thormal insulation, ventilation, ard standardiation.

The program on themel insulation in conncction witin the low-cost housing progrem includos a numbor of soporate projocts. The gonoral purpose of the vorls is to provido data on tho insulating value of materials and constructions where such data are now lackine or conflicting, and to invostigato tho effoct of noisture on the insulatimg qualities of materials. The conomy of using the several materials can thon be detormined.

\section{Heat Transfer throupl Insulatin Materials in Thicinesses up to Four Inches}

For some years the opinion has beon hold in varions quarters that the thermal conductance of fill insulating materials in so-called "full. wall thicknoss" (about $31 / 2$ to 4 inches) is coisideraly loss than would bo calculated from tosts on a nowinch thiclness. A rocent papor on this subjoct contains data to suprort this viow. In adcition, the conductance was found to vary with the tomporature difformec across the samplo during test. There is no apparont reason for these anomalous results, and if truc they aro of considerablo inportance in doternining the relative oconory of ingulating lavons of difncrent thiclness. To dutermine the facts, it is planned to miko reasuraments on fill and other insulations in thichnesses uf to lour inches. For tisis mrpose a three feot square "hot platel conductivity apparatus Will be built with a new type of shect motal mara ring. Tire principlo of this guard ring is to maintain, by electric hoatins, a substantially consteint tomporaturo godiont along a skeet motal strip oxtending from the lot to the cold plate oII around tho edges. The strip is themally insulated from tile edgo os tho hot juate, and the portion of the strip adjacont to tho edse of the hot plate naintainea at tije sarue temporatiue as the lattor by reans of a sopuatio heater. 
If the reaults obtalned or a Iew ligh fill types of insulstion are in areenent wits results alrcacy obtained in sual scale testa, relatively few measurenenss on a large scale will need to be made on insul ting materials, since tests on a amil scale are mach more corvenient and rapid." If, on the obiver hand, the snomalous effects noted bove ere subsumitca $i$ is whole or in pert, a much lonfer oroprar mill be required, the exient of which will devend larpely 0.2 the oreliminery results obtiined.

\section{Heat mransfer tircoy moli Sections}

Dota are alreedy avalleble on the insilatine properties of many Wall types wic are of interest in lowm cost bousing. Sorde of these

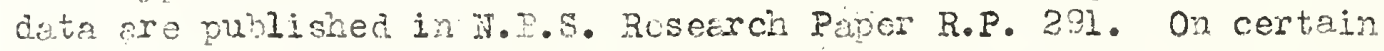
types of ralis wilich have not reen invasiuated sucis as trose containing steel studs ueasuraments will be made on typical sections, Whic secr to be promising irom uther standpoints.

In maring these tosts, the exparatus briefly doscribed in the previous section, vith scine modifications, Fill be utilized. Tro siniiar not piates mill be usea, if necessery, so that tests can be made on 3 by 0 fect panels. Wo cold plates will be required, tie apparatus belng housed in a constant temperature roor.

In this retiod of test, the outside surfece of the rall is exposed to the air while the injiae gurface is either in contact with the jot nlate or senarated from the latwer with a thin flexible insulating layer. In either case, the inside surface coefficient (surfece to air) of the mail is zot obsained, but adequate ita on this ractor in hoat transer througin valls are aiready avalable. The object of the thin insthatize lager between wall surface and hot olat is to interpose a trernel resistrice equiralent to thet jetween tile i.side nir anc. the Mall surface under actual conditions. In this Way very nearly the sane tomperature distribution urer the sirface of the rall. is obtained in the teat as fould occur in service condition. This is of imortance orly in the case of ralis having stcel studs Which cause the instide surface temperature alons the line of the stid

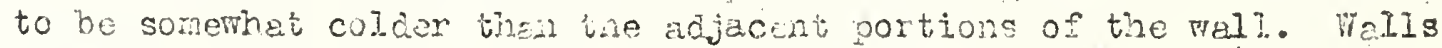
in wich this efect is marked rill becone a nusance on account of the rapid deposition of dust on the wall along the line of the stud, ais accentuation of tie so-calied lath marir pienonenon.

\section{Heat Transfer throng Reslective Insulation}

Considerahle data on retlective types of iusulation ere alreany

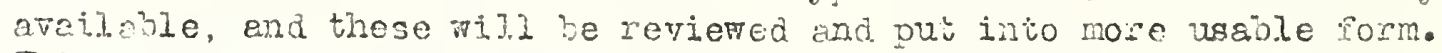
This the of insulation nay fins consiaerable aprication in lor-cost Louses. If it develops that more data are necessary, measurewerts 111 be inede in the lasge conductivity apparauns already nextioned. 


\section{Efect of Moisture o: the The mal Corductivit of Insulatirg Materials}

All naterials consisting primerily of regetable or animal matter are more or less hysroscopic. Men in equilibriun with air at a definite temnerature and relative humidity, these matorials contain definite percentages of water. So long as the relative hunidity remains constant, the offect of moderate chazges in temperature on the amount of wator present is relatively small. The data available on the effect of hysroscopic water on tho conductivity of insulating natorio. s aro vory few and oonflicting.

There is a genorily prevalent idca that the conductivitios of hygroscopic naturials nomally containine a sull percentage of water are much highcr then those of the same naterials in a bone dry condition. A fow tosts made horo indicato that this is not tho case, but in ordor to settle the qrostion a more systomatic investiotion is required. Apocratus is bcing built to mosue the conductivity of insulating matorials undor definito and controllable rolativo humidity cnrditions. our prosent small conductivity apparatus will be inclosed in an uir tirht bor, in which the rolativo hunidity cen bo controllod ber orposing saturated solutions or various netalic salts. If tire effect of moisturc content is not vor largo, the wumber of matorials winch may be used for thermal insulation is preatly increased.

This progran will also include routine moasurements on such ner thermal insulating matorials as nay appear on the market from time to time.

\section{Heat Losses Minroum Doors and Vi:- ows}

Recont gencral uso of effuctivo insulation of walls anà ccilings in dwollings, which is a nocessity it adoquate ail conditioning is to bo roulized, hus procecded without inuch attention to the windows and doors. In nodorn insulatca buildins the hoat lossos through the ordinary windows and doors both by air lealago and by conduction through glass re all out of proportion to losses througit walls and ceilings.

It is proposed to malze a thorouph study of tho hoat losscs in cold weation and the eitrunce of hoat in hot woathor tirough doors and windows and window opcuings, incluaing air lonaje nd hout transfor by conduction and radiation timough the glass. This will inclube not only various kinds of doors, but also single windors, with and without offective weatherstrippires, with and pithout stom vindows, as toll as nem developments in the wa of dovble grazed or otider windums. It will include also mutal windurs since the heat transfor through the motal itselz ofton becones important. letal mincows with both single and double glazin will be studied witin attontion to difforonces which may arjsu from differont aistances apart of the two siazings. 
